\title{
Dynamics of Spirochetemia and Early PCR Detection of Borrelia miyamotoi
}

\author{
Lyudmila Karan, Marat Makenov, Nadezhda Kolyasnikova, Olga Stukolova, \\ Marina Toporkova, Olga Olenkova
}

\begin{abstract}
We investigated whether Borrelia miyamotoi disease can be detected in its early stage by using PCR for borrelial $16 \mathrm{~S}$ rRNA, which molecule (DNA or RNA) is the best choice for this test, and whether spirochetes are present in blood during the acute phase of $B$. miyamotoi disease. A total of 473 patients with a suspected tickborne infection in Yekaterinburg, Russia, in 2009, 2010, and 2015 were enrolled in this study. Blood samples were analyzed by using quantitative PCR or ELISA, and a diagnosis of borreliosis was confirmed for 310 patients. For patients with erythema migrans, $5(3 \%)$ of 167 were positive for $B$. miyamotoi by PCR; for patients without erythema migrans, $65(45 \%)$ of 143 were positive for $B$. miyamotoi by PCR. The median concentration for RNA was 3.8 times that for DNA. Median time for detection of $B$. miyamotoi in blood was 4 days.
\end{abstract}

$B$ orrelia miyamotoi is a relapsing fever spirochete detected in Ixodes persulcatus hard-bodied ticks by Fukunaga et al. in Japan in 1995 (1). Vectors of B. miyamotoi include I. scapularis and I. pacificus ticks in the United States, I. ricinus ticks in Europe, and I. persulcatus and I. ricinus ticks in Russia (2,3). Barbour-Stoenner-Kelly II medium has been used to isolate B. miyamotoi strain HT31 from I. persulcatus ticks and strain FR64b from Apodemus argenteus small Japanese field mice in Asia (1) and strain LB-2001 from I. scapularis ticks in North America (4). Furthermore, borreliosis caused by B. miyamotoi has been confirmed in Russia (3), North America (5-8), Europe (9), and Japan (10).

The diagnosis of Lyme disease (borreliosis) is based primarily on identification of an erythema migrans rash and positive results for serologic laboratory tests (11). However, PCR amplification of $B$. burgdorferi sensu lato DNA is not sensitive enough for routine diagnosis $(11,12)$.

Author affiliations: Central Research Institute of Epidemiology,

Moscow, Russia (L. Karan, M. Makenov, N. Kolyasnikova,

O. Stukolova); Medical Association Novaya Bolnitsa,

Yekaterinburg, Russia (M. Toporkova); Clinical Diagnostic

Center, Yekaterinburg (O. Olenkova)

DOI: https://doi.org/10.3201/eid2405.170829
B. miyamotoi infection usually manifests as an influenza-like disease causing high fever, headache, and myalgia but, in most instances, without erythema migrans (3). $B$. miyamotoi produces glycerophosphodiester phosphodiesterase (glpQ), which is absent in B. burgdorferi sensu lato and is therefore useful for serologic discrimination between relapsing fever and Lyme borreliosis. ELISAs and confirmatory Western blot assays of human serum samples have been used to detect antibodies against $B$. miyamotoi in the Netherlands (13) and the United States (14). Wagemakers et al. (15) detected antibodies against variable small protein 1 and variable large proteins (Vlp15, Vlp16, and Vlp18) in blood samples of patients with $B$. miyamotoi disease. PCR and thin and thick blood smears of peripheral blood stained with Wright stain or Giemsa were used to detect infection in patients suspected of having relapsing fever (10).

Unlike DNA, which is usually present as a single copy per cell, or mRNAs, which constitute the minor population of total cellular RNA, each bacterium contains hundreds to thousands of $16 \mathrm{~S}$ rRNA molecules during the growth phase. Therefore, we hypothesized that an assay based on PCR amplification of cDNA molecules, representing highly and consistently transcribed Borrelia genes such as 16S rRNA, could improve the sensitivity of detection of Borrelia spp. Backstedt et al. (17) reported that leptospiral RNA-based quantitative PCRs (qPCRs) for human blood were $\geq 100$-fold more sensitive than a DNA-based approach. Furthermore, detection of 16S rRNA (e.g., by nucleic acid sequence-based amplification) can distinguish viable from nonviable bacterial cells (18).

Hematogenous dissemination is a major pathogenetic event in Lyme borreliosis. Investigations of level and duration of spirochetemia caused by B. miyamotoi are needed for understanding the pathogenesis of the infection, as well as development of new diagnostic tools.

Our study had 3 goals. First, we sought to determine whether B. miyamotoi disease can be detected in its early stage by using PCR for borrelial $16 \mathrm{~S}$ rRNA. Second, we assessed which molecule (DNA or RNA) is the best choice for this test. Third, we investigated the dynamics 
of B. miyamotoi spirochetemia during the acute phase of the disease.

\section{Methods}

\section{Study Design}

Patients suspected of having tickborne diseases in Russia are hospitalized if they have been bitten by a tick and show development of signs and symptoms of acute infection (fever, chills, headache, fatigue, muscle aches) within a few weeks. A diagnosis of acute Lyme borreliosis was determined by the presence of erythema migrans, detection of borrelial IgM and IgG seroconversion, and detection of pathogen DNA or RNA. In this study, the case definition for B. miyamotoi disease was based only on PCR results. We have previously reported detailed information about case definitions for B. miyamotoi disease (3).

A total of 459 patients admitted to Municipal Clinical Hospital No. 33 (Medical Association Novaya Bolnitsa) in Yekaterinburg, Russia, during May-August 2009 and June-July 2010 for suspected tickborne infection were enrolled in this study. We obtained blood samples from all patients during the first 3 days of hospitalization for analysis by qPCR and ELISA. We performed PCR for detection of $16 \mathrm{~S}$ rRNA of B. miyamotoi, B. burgdorferi sensu lato, Ehrlichia chaffeensis, and E. muris; the 5'-untranslated region gene of tickborne encephalitis virus (TBEV); and the major outer membrane protein 2 gene of Anaplasma phagocytophillum as described (3).

We tested serum samples for borrelial IgM and $\operatorname{IgG}$ and TBEV IgM by ELISA (EUROIMMUN AG, Lubeck, Germany). We estimated the number of copies of $B$. miyamotoi and B. burgdorferi sensu lato DNA and RNA in PCR-positive patient blood samples by using a qPCR for 16S rRNA.

For determining duration of spirochetemia, we collected repeat blood samples from 9 PCR-positive $B$. miyamotoi disease patients in 2010 and 14 B. miyamotoi disease patients admitted to Municipal Clinical Hospital No. 33 in June-July 2015. We collected blood samples from these patients during the first 3 days after admission and then repeatedly for 4 days after initial detection of $B$. miyamotoi in the blood of these patients.

\section{Preparation of Blood Samples}

We used differential centrifugation to separate spirochetes from erythrocytes. Blood samples were centrifuged at 160 $\times g$ for 10 min to pellet erythrocytes. We then transferred $500 \mu \mathrm{L}$ of leukocytes and platelet-rich plasma into $1.5-\mathrm{mL}$ tubes for centrifugation at $10,000 \times g$ for $10 \mathrm{~min}$ to collect leukocytes and spirochetes. We extracted DNA and RNA from the pellet and $100 \mu \mathrm{L}$ of the supernatant by using an AmpliSens Riboprep Kit (Central Research Institute of
Epidemiology, Moscow, Russia). After cell lysis, we divided samples into 2 equal aliquots for separate isolation of B. miyamotoi RNA and DNA targets of $16 \mathrm{~S}$ rRNA. We extracted RNA by using a universal internal RNA recombinant control having a known number of RNA copies per milliliter and DNA by using a universal internal DNA recombinant control having a known number of DNA copies per milliliter. RNA samples were not treated with DNase; therefore, RNA concentrations in this article are RNA/ DNA concentrations.

\section{Molecular Detection of Infection}

We performed PCR-based detection for TBEV, B. burgdorferi sensu lato, A. phagocytophillum, E. chaffeensis, and E. muris by using a commercial multiplex PCR kit (AmpliSens TBEV, B. burgdorferi sensu lato, A. phagocytophillum, E. chaffeensis/E. muris-FL; Central Research Institute of Epidemiology) according to the manufacturer's instructions. We used the B. miyamotoi-specific primers Brm1 5'-CGCTGTAAACGATGCACACTTGGTGTTAATC-3' (forward) and Brm2 5'-CGGCAGTCTCGTCTGAGTCCCCATCT-3' (reverse) at concentrations of $360 \mathrm{nmol} / \mathrm{L}$. The corresponding dye-labeled probe (final concentration $100 \mathrm{nmol} / \mathrm{L}$ ) used was Brm-R6G-5'CCTGGGGAGTATGTTCGCAAGAATGAAACTC-3'$\mathrm{BQH} 1$. PCR conditions were $50^{\circ} \mathrm{C}$ for $15 \mathrm{~min} ; 95^{\circ} \mathrm{C}$ for 15 min; 10 cycles at $95^{\circ} \mathrm{C}$ for $20 \mathrm{~s}, 67^{\circ} \mathrm{C}$ for $50 \mathrm{~s}$, and $72^{\circ} \mathrm{C}$ for $20 \mathrm{~s}$; and 40 cycles at $95^{\circ} \mathrm{C}$ for $20 \mathrm{~s}, 60^{\circ} \mathrm{C}$ for $50 \mathrm{~s}$, and $72^{\circ} \mathrm{C}$ for $20 \mathrm{~s}$. The fluorescence signal was recorded at the $60^{\circ} \mathrm{C}$ step for the last 40 cycles. Each run included negative controls and 2 positive recombinant DNA controls (a B. miyamotoi 16S rRNA gene fragment and an internal control having $10^{4}-10^{6}$ copies $/ \mathrm{mL}$ ) as standards.

We used B. burgdorferi sensu lato-specific primers Brb1 5'-TGCAAGTCAAACGGGATGTAGCAATACA-3' (forward) and Brb2 5'-GGCTTCCTTTCATCAATTAACAAA-3' (reverse) at concentrations of $360 \mathrm{nmol} / \mathrm{L}$. The corresponding dye-labeled probe (final concentration $100 \mathrm{nmol} / \mathrm{L}$ ) was Brb-R6G-5'-TAGGTAGAT-BQH1CATCCACGCGTTACTACC-3'. PCR conditions were $50^{\circ} \mathrm{C}$ for $15 \mathrm{~min} ; 95^{\circ} \mathrm{C}$ for $15 \mathrm{~min}$; and 45 cycles at $95^{\circ} \mathrm{C}$ for $10 \mathrm{~s}$ and $60^{\circ} \mathrm{C}$ for $20 \mathrm{~s}$. The fluorescence signal was recorded at the $60^{\circ} \mathrm{C}$ step for the last 45 cycles. Each run included negative controls and 2 positive recombinant DNA controls (a B. burgdorferi sensu lato 16S rRNA gene fragment and an internal control having $10^{4}-10^{6}$ copies $/ \mathrm{mL}$ ) as standards.

The RNA template was subjected to reverse transcription (Thermo Fisher Scientific, Waltham, MA, USA). In 2015, a commercial PCR kit (AmpliSens B. miyamotoiFL; Central Research Institute of Epidemiology) was used according to the manufacturer's instructions for B. miyamotoi $g \operatorname{lp} Q$ gene screening of patients with suspected tickborne diseases. 


\section{ELISA}

We tested serum samples collected at the time of hospitalization and 1-2 weeks later for borrelial IgM and IgG. We obtained serologic evidence of exposure to Borrelia spp. by using 2 ELISAs (EI 2132-9601 M and EI 21329601-2 G; EUROIMMUN AG) and detected TBEV IgM by using a semiquantitative ELISA (EI 2661-9601 M; EUROIMMUN AG).

\section{Data Analysis}

We used the Wilcoxon signed-rank test for comparing copy numbers of $B$. miyamotoi RNA and DNA in blood samples and the Kaplan-Meier estimator to assess persistence of DNA or RNA of pathogens in blood. We performed time-to-event analysis by using the following assumptions: 1) starting time was the first day of illness; 2) observations for no antimicrobial drug treatment were complete data; 3 ) observations for late antimicrobial drug treatment (when DNA or RNA were eliminated from blood before start of treatment) were complete data; and 4) observations for antimicrobial drug treatment were incomplete data (right censored). The Kaplan-Meier estimator assumes that at any time, patients who are censored have the same survival prospects as those who continue to be followed up (19).

We used the Clopper-Pearson interval for calculating CIs for proportions. Descriptive statistics are given as mean and SD or median and interquartile range (IQR). We analyzed data by using SPSS software (IBM, Armonk, NY, USA) or R software (https://www.r-project.org/).

\section{Results}

\section{Study Population}

During 2009-2010, of 310 (67.5\%, 95\% CI 63.0\%-71.8\%) patients with borreliosis, 34 (7.4\%, 95\% CI 5.2\%-10.2\%) patients were positive for TBEV, and 115 (25.1\%, 95\% CI $21.2 \%-29.3 \%$ ) were positive for other inflammatory diseases. Genetic markers of anaplasmosis and ehrlichiosis were not detected.
Erythema migrans as a symptom was observed in 167 (53.9\%, 95\% CI 48.1\%-59.5\%) patients with borreliosis and was absent in the remaining $143(46.1 \%, 95 \% \mathrm{CI}$ 40.5\%-51.9\%) patients. Among patients with erythema migrans, DNA or RNA of the B. burgdorferi sensu lato $16 \mathrm{~S}$ rRNA gene was detected by qPCR in $18.6 \%(95 \%$ CI $13.0 \%-25.3 \%)$, and $3.0 \%$ (95\% CI $0.4 \%-5.2 \%)$ were positive for B. miyamotoi (Table 1). For patients without erythema migrans, genetic markers of $B$. burgdorferi sensu lato were found in $3.5 \%(95 \%$ CI $1.1 \%-8.0 \%)$, and $45.5 \%(95 \%$ CI $37.1 \%-54.0 \%)$ were positive for B. miyamotoi. One case-patient was co-infected with $B$. burgdorferi sensu lato and B. miyamotoi. For $51.0 \%$ (95\% CI $42.6 \%-59.5 \%$ ) of patients, borreliosis was confirmed by determination of antibody seroconversion by ELISA only.

\section{RNA and DNA Concentrations}

Because onset of B. miyamotoi disease is acute, patients are usually admitted to a hospital during the first 3 days of the disease in Russia. In our study, $79 \%$ of patients were admitted to the hospital during the first 3 days, which indicates that concentrations of B. miyamotoi RNA or DNA are accurate for this period.

The maximum pathogen RNA concentration was observed on day 1 of the disease (Figure 1, panel A). On day 2 , RNA copy number varied widely (median 3,700-45,360 copies $/ \mathrm{mL}$ ); it remained in this range on subsequent days. The concentration of B. miyamotoi DNA varied in a similar way (Figure 1, panel B); the highest value of 9,085 copies $/ \mathrm{mL}$ was found on the first day, after which the value decreased to 797.5 copies $/ \mathrm{mL}$. Because there were only 2 observations on day 6, observed ranges of DNA (and RNA) concentrations are speculative. The Wilcoxon signed-rank test showed that the copy number of RNA in blood was significantly higher than the copy number of DNA $(p<0.001)$. The RNA:DNA ratio also showed a wide range (median ratio 3.8, IQR 2.1-7.5).

Early Lyme disease is usually manifested only by erythema migrans; thus, patients are often hospitalized late in their illness. The median time gap between onset of

\begin{tabular}{|c|c|c|c|c|}
\hline Quantitative PCR for $16 \mathrm{~S}$ rRNA gene & No. patients & No. ELISA positive & No. ELISA negative & ND \\
\hline \multicolumn{5}{|l|}{ With erythema migrans } \\
\hline Borrelia burgdorferi sensu lato & 31 & 30 & 1 & 0 \\
\hline B. miyamotoi & 5 & 5 & 0 & 0 \\
\hline PCR negative & 131 & 81 & 39 & 11 \\
\hline Total & 167 & 116 & 40 & 11 \\
\hline \multicolumn{5}{|l|}{ Without erythema migrans } \\
\hline B. burgdorferi sensu lato & 4 & 4 & 0 & 0 \\
\hline B. miyamotoi & 65 & 55 & 10 & 0 \\
\hline B. burgdorferi sensu lato plus $B$. miyamotoi & 1 & 0 & 1 & 0 \\
\hline PCR negative & 73 & 73 & 0 & 0 \\
\hline Total & 143 & 132 & 11 & 0 \\
\hline
\end{tabular}


disease and hospitalization was 6 days (IQR 3-9 days). We showed that PCR diagnosis of Lyme disease has low sensitivity. Consequently, B. burgdorferi sensu lato RNA and DNA concentration varied; the median RNA concentration was 585.0 copies $/ \mathrm{mL}$ (IQR 305.3-1,392.5 copies $/ \mathrm{mL}$ ), and the median DNA concentration was 19.9 copies/mL (IQR 8.1-121.2 copies $/ \mathrm{mL}$ ). The concentration of B. burgdorferi sensu lato RNA was also significantly higher than that for DNA ( $p<0.001)$, which resulted in a greater RNA:DNA ratio (median 40.9, IQR 13.3-77.4). Differences between $B$. miyamotoi and B. burgdorferi sensu lato for concentrations of RNA and DNA were significant $(\mathrm{z}=-5.77, \mathrm{p}<0.001$, by Mann-Whitney U-test).

B. miyamotoi DNA or RNA were detected in blood samples up to day 30 of disease (Figure 2, panel A). However, despite such a wide range, $90 \%$ of all observations were in the first 8 days of the disease. We showed in a previous study (20) that $7(9.1 \%)$ positive samples, which were obtained from patients given a diagnosis of B. miyamoto $i$ disease during the second week of disease (or later), were assumed to be caused by a relapse of fever. However, this assumption could not be confirmed because of lack of availability of clinical materials. Pathogen DNA or RNA were detected in blood samples from patients with Lyme borreliosis obtained up to day 24 of disease (Figure 2, panel B).

The study showed a high number of false-negative PCR results in patients with and without EM (Table 1). The time gap between onset of disease and blood sampling can affect results of blood tests. Therefore, all blood samples from the group of patients without EM were obtained based on the time after onset of symptoms. We found that blood samples from B. miyamotoi PCR-positive patients were obtained significantly earlier $(\mathrm{z}=-3.29, \mathrm{p}<0.001$, by Mann-Whitney U-test). The median time of blood sampling was 2.0 days (IQR 2.0-4.0 days) for PCR-positive patients without EM and 4.0 days (IQR 2.3-6.0 days) for PCR-negative patients without EM after initial symptoms. Therefore, PCR is
A

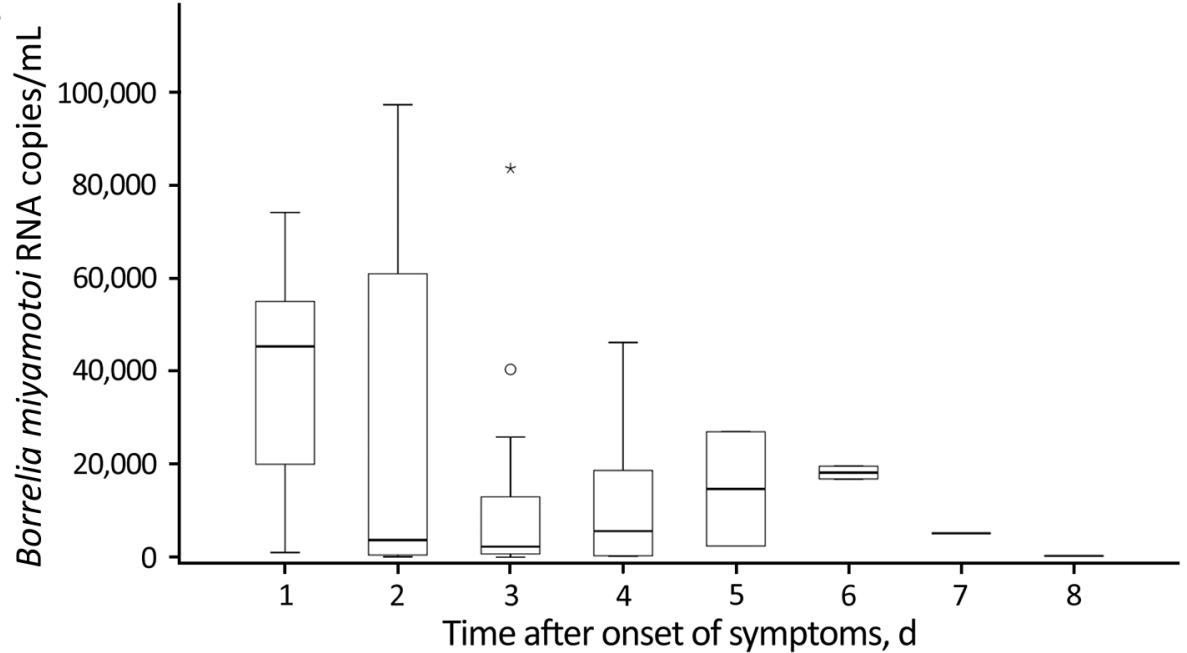

B

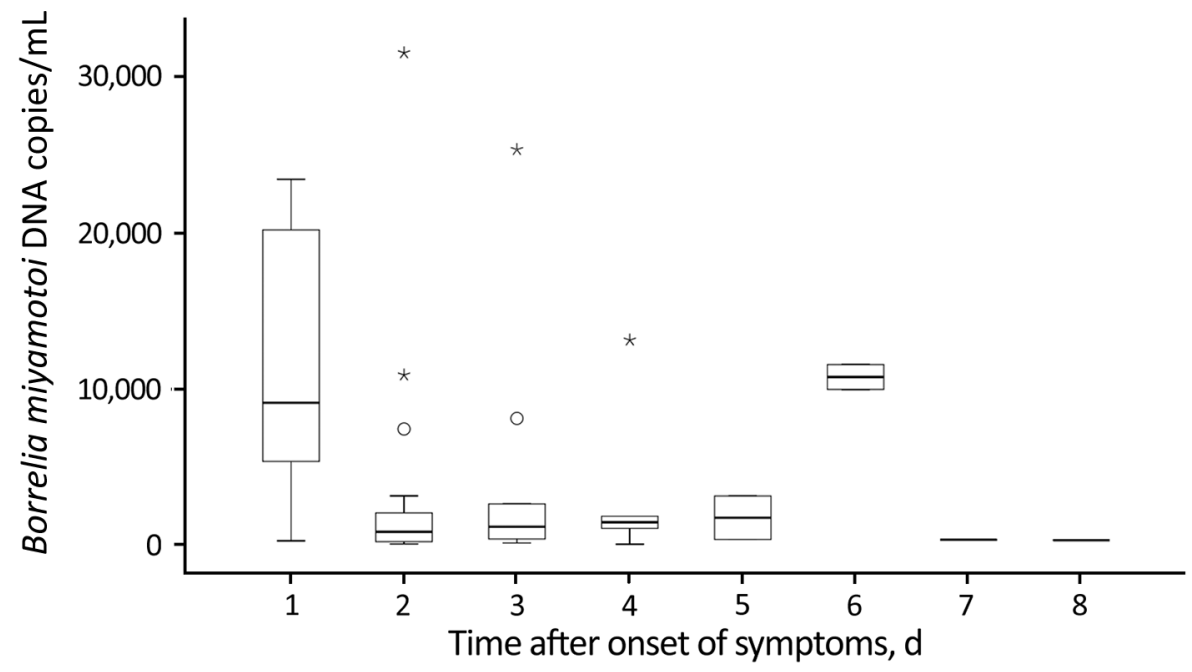

Figure 1. Concentration of Borrelia miyamotoi A) RNA and $B$ ) DNA in blood samples from patients with $B$. miyamotoi disease during disease progression, Yekaterinburg, Russia, 2009-2010. Blood samples were obtained before antimicrobial drug therapy was given. Boxes indicate interquartile ranges (IQRs), horizontal bars indicate medians, and error bars indicate $1.5 \times I Q R$. Circles indicate moderate outliers $(1.5 \times-3 \times$ IQR, 238,700 copies/mL), and asterisks indicate extreme outliers (>3× IQR, 280,000 420,000 copies/mL). 

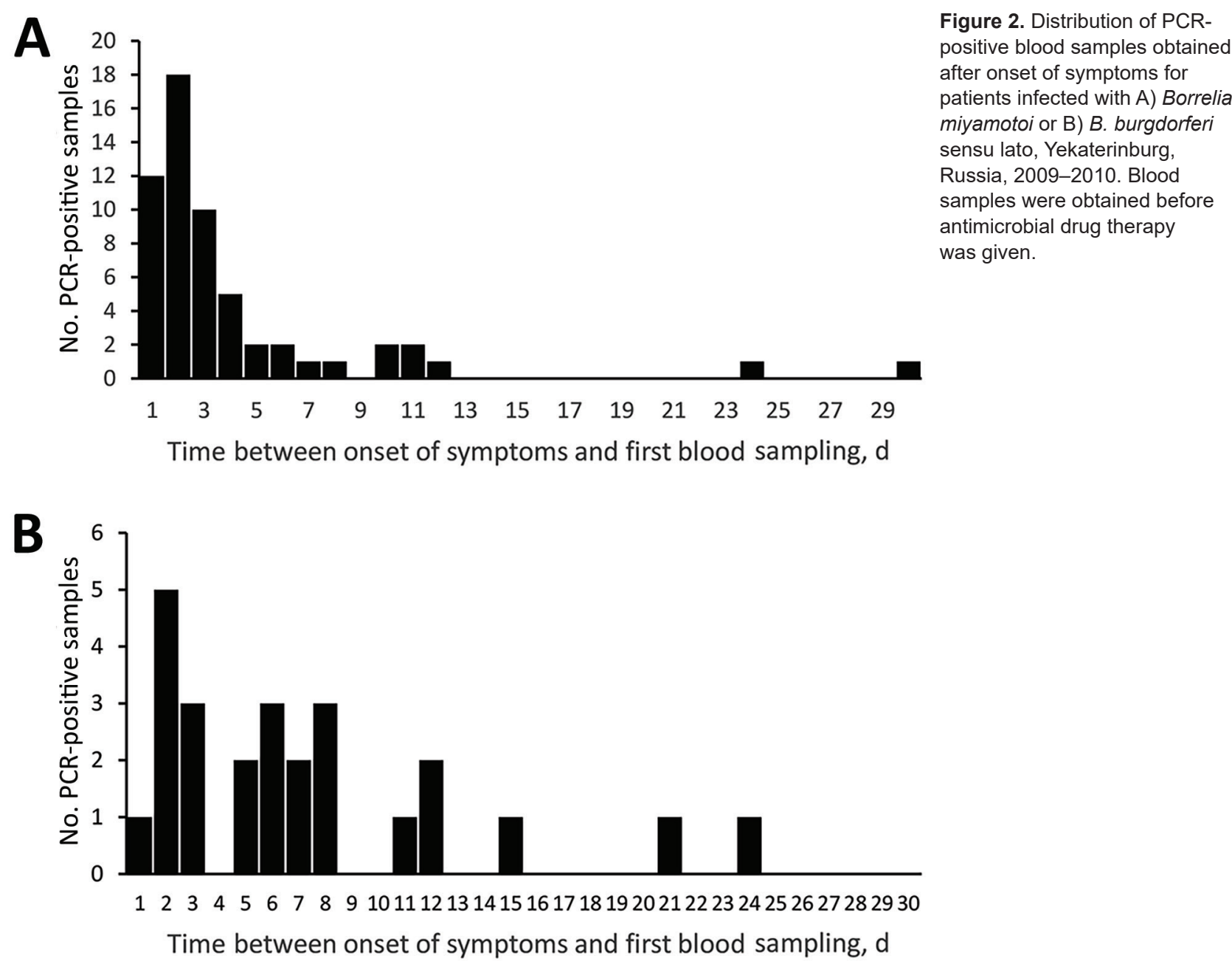

applicable for diagnosis of B. miyamotoi disease only during the first few days of the disease.

\section{Duration of Spirochetemia}

In 2010 and 2015, we obtained blood samples repeatedly during the first 6 days of disease from 23 patients with confirmed B. miyamotoi disease (Table 2) and used data for these samples to estimate the duration of spirochetemia. We excluded samples from patients who had started antimicrobial drug therapy before or at the same time as the blood tests and those from patients who had a time gap between blood samples $>2$ days. We performed time-toevent analysis for 17 patients. Pathogen DNA or RNA was detected in blood up to day 5 of illness (Table 2), and all samples showed negative results on day 6 of illness. Median time for detection of pathogen DNA or RNA in blood was 4.0 days (95\% CI 3.1-4.9 days) (Figure 3).

\section{Discussion}

Borreliosis is the most prevalent tickborne disease in Russia $(21,22)$. Our findings showed that, in Yekaterinburg, $\approx 23 \%$ cases of borreliosis (confirmed clinically, serologically, or by PCR) were caused B. miyamotoi. Findings that indicated that $B$. miyamotoi disease might not be a rare infection have been previously suggested for the United States $(8,14,23)$ and the Netherlands (13).

We found that erythema migrans was not apparent in $70(93 \%)$ patients with B. miyamotoi disease, and only in $7 \%$ of case-patients was erythema migrans manifested. We obtained data for the 5 PCR-confirmed case-patients with $B$. miyamotoi disease and erythema migrans and the case-patient co-infected with $B$. burgdorferi sensu lato and $B$. miyamotoi. We believe that these 5 patients were also co-infected with Borrelia spp. and that the B. burgdorferi sensu lato DNA was not detected because of the low sensitivity of the PCR. Additional research is needed to test this assumption. Recent studies reported that in the United States, $14 \%$ of patients with $B$. miyamotoi disease were coinfected with $B$. burgdorferi $(7,23)$, including a patient with erythema migrans (23).

Our study showed poor sensitivity $(\approx 11 \%)$ of qPCR detection for 16S rRNA for B. burgdorferi sensu lato. 
Spirochetemia and PCR Detection of B. miyamotoi

Table 2. Dynamics of Borrelia miyamotoi RNA and DNA load in blood samples from 23 patients with Borrelia miyamotoi disease, Yekaterinburg, Russia, 2010 and 2015*

\begin{tabular}{|c|c|c|c|c|c|c|c|c|c|c|}
\hline \multirow{3}{*}{$\begin{array}{l}\text { Year and } \\
\text { patient ID }\end{array}$} & \multicolumn{10}{|c|}{ PCR product for B. miyamotoi, copies/mL } \\
\hline & \multicolumn{2}{|c|}{ Day 1} & \multicolumn{2}{|c|}{ Day 2} & \multicolumn{2}{|c|}{ Day 3} & \multicolumn{2}{|c|}{ Day 4} & \multicolumn{2}{|c|}{ Day 5} \\
\hline & RNA & DNA & RNA & DNA & RNA & DNA & RNA & DNA & RNA & DNA \\
\hline \multicolumn{11}{|l|}{2010} \\
\hline 1 & NA & NA & $1.9 \times 10^{4}$ & $3.3 \times 10^{4}$ & - & - & $\mathrm{NA}$ & NA & NA & NA \\
\hline 2 & NA & NA & $1.9 \times 10^{4}$ & $5.5 \times 10^{4}$ & NA & NA & NA & NA & $3.1 \times 10^{3}$ & $2.7 \times 10^{4}$ \\
\hline 3 & NA & NA & $2.0 \times 10^{3}$ & $2.4 \times 10^{3}$ & - & - & - & - & - & - \\
\hline 4 & NA & NA & $9.5 \times 10^{2}$ & $3.4 \times 10^{3}$ & $3.4 \times 10^{2}$ & $7.1 \times 10^{2}$ & - & - & - & - \\
\hline 5 & NA & NA & $1.6 \times 10^{3}$ & $1.2 \times 10^{4}$ & - & $8.5 \times 10^{1}$ & - & - & - & - \\
\hline 6 & NA & NA & NA & NA & $1.1 \times 10^{3}$ & $2.6 \times 10^{4}$ & - & - & NA & NA \\
\hline 7 & NA & NA & $6.7 \times 10^{3}$ & $2.7 \times 10^{4}$ & - & - & NA & NA & NA & NA \\
\hline 8 & NA & NA & $6.5 \times 10^{2}$ & $2.8 \times 10^{3}$ & - & - & NA & NA & NA & NA \\
\hline 9 & NA & NA & $9.9 \times 10^{3}$ & $1.7 \times 10^{4}$ & - & - & NA & NA & NA & NA \\
\hline \multicolumn{11}{|l|}{2015} \\
\hline 10 & NA & NA & $1.2 \times 10^{4}$ & $8.2 \times 10^{3}$ & $2.2 \times 10^{1}$ & - & - & - & - & - \\
\hline 11 & NA & NA & $2.8 \times 10^{5}$ & $9.2 \times 10^{4}$ & $1.0 \times 10^{3}$ & $3.2 \times 10^{2}$ & - & - & - & - \\
\hline 12 & NA & NA & $5.4 \times 10^{4}$ & $1.7 \times 10^{4}$ & - & - & - & - & - & - \\
\hline 13 & NA & NA & $8.7 \times 10^{4}$ & $8.8 \times 10^{3}$ & - & - & - & - & - & - \\
\hline 14 & NA & NA & $6.1 \times 10^{4}$ & $3.2 \times 10^{4}$ & NA & NA & - & - & - & - \\
\hline 15 & NA & NA & NA & NA & $1.8 \times 10^{3}$ & $1.3 \times 10^{3}$ & NA & NA & NA & NA \\
\hline 16 & $2.0 \times 10^{4}$ & $1.9 \times 10^{4}$ & NA & NA & NA & NA & $2.0 \times 10^{2}$ & $1.3 \times 10^{1}$ & NA & NA \\
\hline 17 & NA & NA & NA & NA & $3.4 \times 10^{3}$ & $6.9 \times 10^{2}$ & - & - & - & - \\
\hline 18 & NA & NA & $1.9 \times 10^{4}$ & $7.2 \times 10^{4}$ & - & - & - & - & - & - \\
\hline 19 & NA & NA & $4.3 \times 10^{4}$ & $1.4 \times 10^{4}$ & $9.7 \times 10^{1}$ & $3.0 \times 10^{1}$ & - & - & - & - \\
\hline 20 & NA & NA & $4.2 \times 10^{5}$ & $9.6 \times 10^{4}$ & - & - & $3.2 \times 10^{2}$ & $8.0 \times 10^{1}$ & - & - \\
\hline 21 & NA & NA & $2.9 \times 10^{2}$ & $6.5 \times 10^{1}$ & _ & _ & _ & - & - & _ \\
\hline 22 & NA & NA & NA & NA & $3.3 \times 10^{2}$ & $2.3 \times 10^{3}$ & - & - & - & - \\
\hline 23 & NA & NA & NA & NA & $1.3 \times 10^{4}$ & $4.1 \times 10^{3}$ & NA & NA & - & _ \\
\hline
\end{tabular}

In comparison, the sensitivity of PCR for B. burgdorferi sensu lato varied widely $(7.5 \%-78.1 \%)(12,24,25)$. Several studies have reported low sensitivity of PCR for $B$. burgdorferi sensu lato DNA for routine diagnostic purposes because of low numbers of spirochetes circulating in the bloodstream during acute infection $(8,12,26-29)$. For relapsing fever caused by Borrelia spp., the number of $g l p Q$ gene copies for $B$. duttonii and $B$. reccurentis ranged from $10^{2}$ to $10^{5}$ copies $/ \mathrm{mL}$ for $7(0.3 \%)$ of 2,057 healthy participants and from $10^{3}$ to $10^{8}$ copies $/ \mathrm{mL}$ for 15 $(3.9 \%)$ of 382 patients with fever who were surveyed in Tanzania (16). The number of copies of the B. miyamotoi gene in serum samples of 2 patients in Japan was $7.2 \times$ $10^{3}$ and $2.8 \times 10^{4}$ copies $/ \mathrm{mL}$ by $16 \mathrm{~S}$ rRNA qPCR (30). A mean copy number of 7,787 copies $/ \mathrm{mL}$ was reported for $B$. miyamotoi disease patients in the northeastern United States (23).

The number of copies of the $B$. miyamotoi gene in serum samples from 2 patients in Japan was $7.2 \times 10^{3}$ and $2.8 \times 10^{4}$ copies $/ \mathrm{mL}$ by $16 \mathrm{~S}$ rRNA qPCR (30). A mean copy number of 7,787 copies $/ \mathrm{mL}$ was reported for $B$. $m i$ yamotoi disease patients in the northeastern United States (23). Our study identified the bacterial load in blood samples of patients with B. miyamotoi disease $(\leq 9,085$ copies/ $\mathrm{mL}$ ) and showed that an early diagnosis of this disease is possible if a PCR for the 16S rRNA gene is used. The concentration of $B$. miyamotoi RNA in blood is higher than that for DNA. We found a low median RNA:DNA ratio $(\approx 4)$, which indicates that use of RNA as the target molecule is inappropriate.

We obtained data on the duration of spirochetemia, which contributes to the early diagnosis of $B$. miyamoto $i$ disease. It is possible to detect borrelial DNA by PCR during the first 3 days of the disease. However, bacterial DNA is then no longer detectable in the blood, so PCR detection is ineffective after 4 days. We detected 73 Borrelia spp. ELISA-positive patients without erythema migrans who seroconverted within the observation period and were PCR negative for both Borrelia spp. On average, these samples were obtained later than B. miyamotoi PCR-positive samples, suggesting that they might have been collected after the end of the period of spirochetemia and caused the PCRnegative results.

We characterized the duration of B. miyamotoi spirochetemia during acute illness. Although there was no strong clinical confirmation, our data showed that B. miyamotoi DNA and RNA might be detected in the circulation within 30 days after onset of disease. This extended parasitemia is probably related to disease relapse (20). Lee et al. (8) provided indirect results for B. miyamotoi spirochetemia and detected B. miyamotoi DNA in blood samples of 4 patients during the period with little tick exposure in the northeastern United States. These authors suggested that this off-season spirochetemia with a low bacterial 


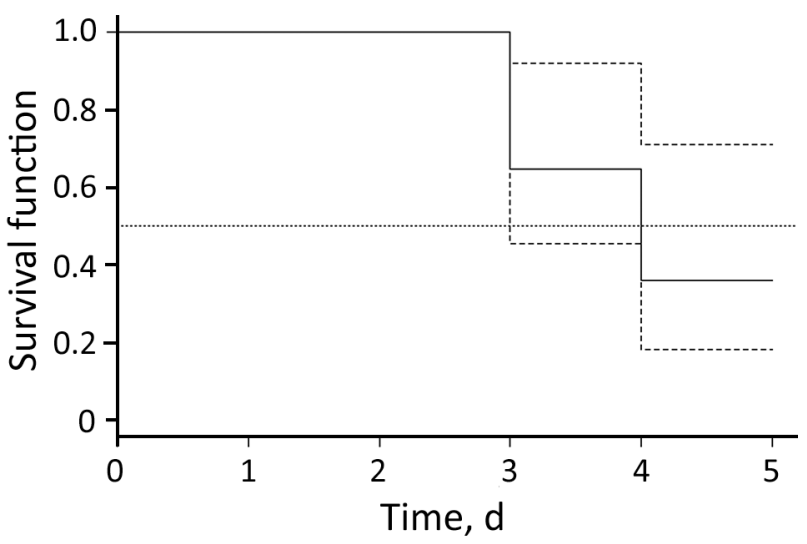

Figure 3. Kaplan-Meier estimates of Borrelia miyamotoi RNA or DNA in blood samples from patients with $B$. miyamotoi disease (solid line), Yekaterinburg, Russia, 2010 and 2015. Dashed line indicates $95 \% \mathrm{Cls}$, and dotted line indicates median. Observations during antimicrobial drug therapy represent incomplete data (right censored).

density was most likely the result of bacteria being dislodged periodically from persistent deep-tissue lesions (8). Thus, a long-term study of pathogen persistence is required.

The duration of B. miyamotoi spirochetemia is relatively short. Thus, the true number of ambulatory and hospitalized patients infected with $B$. miyamotoi will not be known until a sensitive, reliable, diagnostic laboratory test (i.e., serologic test) is available to detect causative agents in patients with acute infections in disease-endemic areas.

This study was supported by the Russian Scientific Foundation (project no. 15-15-00072).

\section{About the Author}

Ms. Karan is the head of the Research Group of Vector-Borne and Zoonotic Diseases, Central Research Institute of Epidemiology, Moscow, Russia. Her research interests include tickborne diseases, mosquitoborne diseases, and molecular diagnostics of these diseases.

\section{References}

1. Fukunaga M, Takahashi Y, Tsuruta Y, Matsushita O, Ralph D, McClelland M, et al. Genetic and phenotypic analysis of Borrelia miyamotoi sp. nov., isolated from the ixodid tick Ixodes persulcatus, the vector for Lyme disease in Japan. Int J Syst Bacteriol. 1995;45:804-10. http://dx.doi.org/10.1099/ 00207713-45-4-804

2. Crowder CD, Carolan HE, Rounds MA, Honig V, Mothes B, Haag H, et al. Prevalence of Borrelia miyamotoi in Ixodes ticks in Europe and the United States. Emerg Infect Dis. 2014;20:1678-82. http://dx.doi.org/10.3201/eid2010.131583

3. Platonov AE, Karan LS, Kolyasnikova NM, Makhneva NA, Toporkova MG, Maleev VV, et al. Humans infected with relapsing fever spirochete Borrelia miyamotoi, Russia. Emerg Infect Dis. 2011;17:1816-23. http://dx.doi.org/10.3201/ eid1710.101474
4. Hue F, Ghalyanchi Langeroudi A, Barbour AG. Chromosome sequence of Borrelia miyamotoi, an uncultivable tick-borne agent of human infection. Genome Announc. 2013;1:e00713-13. http://dx.doi.org/10.1128/genomeA.00713-13

5. Chowdri HR, Gugliotta JL, Berardi VP, Goethert HK, Molloy PJ, Sterling SL, et al. Borrelia miyamotoi infection presenting as human granulocytic anaplasmosis: a case report. Ann Intern Med. 2013;159:21-7. http://dx.doi.org/10.7326/0003-4819-159-1201307020-00005

6. Gugliotta JL, Goethert HK, Berardi VP, Telford SR III. Meningoencephalitis from Borrelia miyamotoi in an immunocompromised patient. N Engl J Med. 2013;368:240-5. http://dx.doi.org/10.1056/NEJMoa1209039

7. Krause PJ, Narasimhan S, Wormser GP, Rollend L, Fikrig E, Lepore T, et al. Human Borrelia miyamotoi infection in the United States. N Engl J Med. 2013;368:291-3. http://dx.doi.org/10.1056/ NEJMc1215469

8. Lee SH, Vigliotti JS, Vigliotti VS, Jones W, Moorcroft TA, Lantsman K. DNA sequencing diagnosis of off-season spirochetemia with low bacterial density in Borrelia burgdorferi and Borrelia miyamotoi infections. Int J Mol Sci. 2014;15:1136486. http://dx.doi.org/10.3390/ijms150711364

9. Hovius JWR, de Wever B, Sohne M, Brouwer MC, Coumou J, Wagemakers A, et al. A case of meningoencephalitis by the relapsing fever spirochaete Borrelia miyamotoi in Europe. Lancet. 2013;382:658. http://dx.doi.org/10.1016/S0140-6736 (13)61644-X

10. Sato K, Takano A, Konnai S, Nakao M, Ito T, Koyama K, et al. Human infections with Borrelia miyamotoi, Japan. Emerg Infect Dis. 2014;20:1391-3. http://dx.doi.org/10.3201/eid2008.131761

11. Chmielewska-Badora J, Cisak E, Wójcik-Fatla A, Zwoliński J, Buczek A, Dutkiewicz J. Correlation of tests for detection of Borrelia burgdorferi sensu lato infection in patients with diagnosed borreliosis. Ann Agric Environ Med. 2006;13:307-11.

12. Liveris D, Schwartz I, McKenna D, Nowakowski J, Nadelman RB, DeMarco J, et al. Quantitation of cell-associated borrelial DNA in the blood of Lyme disease patients with erythema migrans. Eur J Clin Microbiol Infect Dis. 2012;31:791-5. http://dx.doi.org/ 10.1007/s10096-011-1376-x

13. Jahfari S, Herremans T, Platonov AE, Kuiper H, Karan LS, Vasilieva O, et al. High seroprevalence of Borrelia miyamotoi antibodies in forestry workers and individuals suspected of human granulocytic anaplasmosis in the Netherlands. New Microbes New Infect. 2014;2:144-9. http://dx.doi.org/10.1002/nmi2.59

14. Krause PJ, Narasimhan S, Wormser GP, Barbour AG, Platonov AE, Brancato J, et al.; Tick Borne Diseases Group. Borrelia miyamotoi sensu lato seroreactivity and seroprevalence in the northeastern United States. Emerg Infect Dis. 2014;20:1183-90. http://dx.doi.org/10.3201/eid2007.131587

15. Wagemakers A, Koetsveld J, Narasimhan S, Wickel M, Deponte K, Bleijlevens B, et al. Variable major proteins as targets for specific antibodies against Borrelia miyamotoi. J Immunol. 2016;196:418595. http://dx.doi.org/10.4049/jimmunol.1600014

16. Reller ME, Clemens EG, Schachterle SE, Mtove GA, Sullivan DJ, Dumler JS. Multiplex 5' nuclease-quantitative PCR for diagnosis of relapsing fever in a large Tanzanian cohort. J Clin Microbiol. 2011;49:3245-9. http://dx.doi.org/10.1128/JCM.00940-11

17. Backstedt BT, Buyuktanir O, Lindow J, Wunder EA Jr, Reis MG, Usmani-Brown S, et al. Efficient detection of pathogenic leptospires using $16 \mathrm{~S}$ ribosomal RNA. PLoS One. 2015;10:e128913. http://dx.doi.org/10.1371/journal.pone.0128913

18. Simpkins SA, Chan AB, Hays J, Pöpping B, Cook N. An RNA transcription-based amplification technique (NASBA) for the detection of viable Salmonella enterica. Lett Appl Microbiol. 2000;30:75-9. http://dx.doi.org/10.1046/ j.1472-765x.2000.00670.x 
19. Jager KJ, van Dijk PC, Zoccali C, Dekker FW. The analysis of survival data: the Kaplan-Meier method. Kidney Int. 2008; 74:560-5. http://dx.doi.org/10.1038/ki.2008.217

20. Sarksyan DS, Maleev VV, Platonov AE, Platonova OV, Karan LS. Relapsing (recurrent) disease caused by Borrelia miyamotoi [in Russian]. Ter Arkh. 2015;87:18-25. http://dx.doi.org/10.17116/ terarkh2015871118-25

21. Korenberg EI. Comparative ecology and epidemiology of Lyme disease and tick-borne encephalitis in the former Soviet Union. Parasitol Today. 1994;10:157-60. http://dx.doi.org/10.1016/ 0169-4758(94)90269-0

22. Korenberg EI, Gorban LY, Kovalevskii YV, Frizen VI, Karavanov AS. Risk for human tick-borne encephalitis, borrelioses, and double infection in the pre-Ural region of Russia. Emerg Infect Dis. 2001;7:459-62. http://dx.doi.org/ 10.3201/eid0703.017319

23. Molloy PJ, Telford SR III, Chowdri HR, Lepore TJ, Gugliotta JL, Weeks KE, et al. Borrelia miyamotoi disease in the northeastern United States: a case series. Ann Intern Med. 2015;163:91-8. http://dx.doi.org/10.7326/M15-0333

24. Kondrusik M, Grygorczuk S, Skotarczak B, Wodecka B, Rymaszewska A, Pancewicz S, et al. Molecular and serological diagnosis of Borrelia burgdorferi infection among patients with diagnosed erythema migrans. Ann Agric Environ Med. 2007; 14:209-13

25. Santino I, Berlutti F, Pantanella F, Sessa R, del Piano M. Detection of Borrelia burgdorferi sensu lato DNA by PCR in serum of patients with clinical symptoms of Lyme borreliosis. FEMS Microbiol Lett. 2008;283:30-5. http://dx.doi.org/10.1111/ j.1574-6968.2008.01134.x
26. Coulter P, Lema C, Flayhart D, Linhardt AS, Aucott JN, Auwaerter PG, et al. Two-year evaluation of Borrelia burgdorferi culture and supplemental tests for definitive diagnosis of Lyme disease. J Clin Microbiol. 2005;43:5080-4. http://dx.doi.org/ 10.1128/JCM.43.10.5080-5084.2005

27. Girard YA, Fedorova N, Lane RS. Genetic diversity of Borrelia burgdorferi and detection of B. bissettii-like DNA in serum of north-coastal California residents. J Clin Microbiol. 2011;49: 945-54. http://dx.doi.org/10.1128/JCM.01689-10

28. Goodman JL, Bradley JF, Ross AE, Goellner P, Lagus A, Vitale B, et al. Bloodstream invasion in early Lyme disease: results from a prospective, controlled, blinded study using the polymerase chain reaction. Am J Med. 1995;99:6-12. http://dx.doi.org/10.1016/ S0002-9343(99)80097-7

29. Wallach FR, Forni AL, Hariprashad J, Stoeckle MY, Steinberg CR, Fisher L, et al. Circulating Borrelia burgdorferi in patients with acute Lyme disease: results of blood cultures and serum DNA analysis. J Infect Dis. 1993;168:1541-3. http://dx.doi.org/10.1093/ infdis/168.6.1541

30. Halperin T, Orr N, Cohen R, Hasin T, Davidovitch N, Klement E, et al. Detection of relapsing fever in human blood samples from Israel using PCR targeting the glycerophosphodiester phosphodiesterase $(g \operatorname{lp} Q)$ gene. Acta Trop. 2006;98:189-95. http://dx.doi.org/10.1016/j.actatropica.2006.04.004

Address for correspondence: Marat Makenov, Central Research Institute of Epidemiology, Moscow 111123, Russia; email: mmakenov@gmail.com

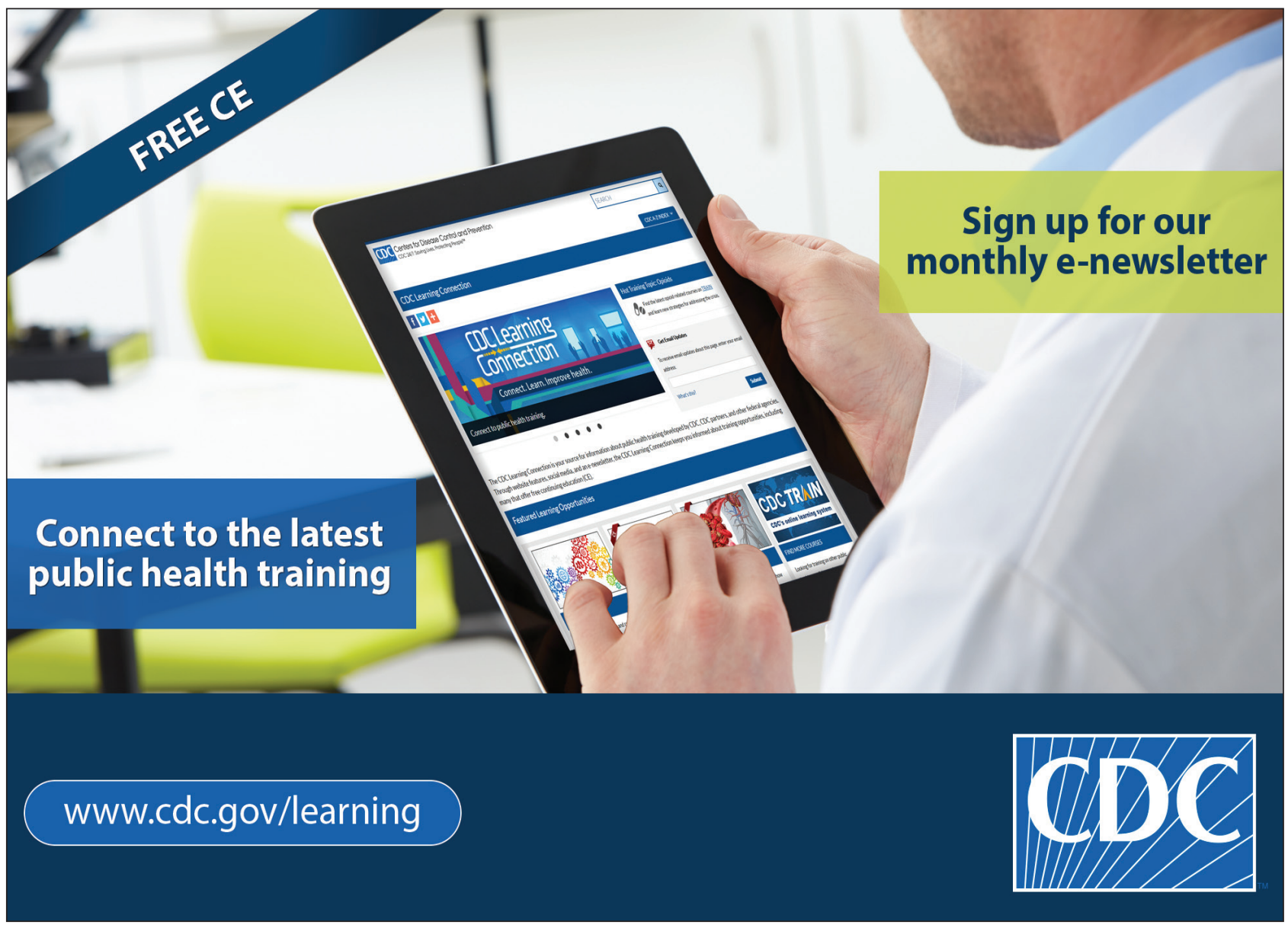

